Article

\title{
Improving Social Acceptance of Waste-to-Energy Incinerators in China: Role of Place Attachment, Trust, and Fairness
}

\author{
Guanghui Hou ${ }^{1} \mathbb{C}$, Tong Chen ${ }^{1}$, Ke Ma ${ }^{2, *}$, Zhiming Liao ${ }^{1}$, Hongmei Xia ${ }^{1}$ and Tianzeng Yao ${ }^{1}$ \\ 1 College of Management and Economics, Tianjin University, No. 92, Weijin Road, Nankai District, \\ Tianjin 300072, China; houguanghui@tju.edu.cn (G.H.); ct88@tju.edu.cn (T.C.); \\ Liaozhiming@tju.edu.cn (Z.L.); 15297192989@163.com (H.X.); ytzcl@126.com (T.Y.) \\ 2 BNU Business school of Beijing Normal University, No. 19, XinJieKouWai St., HaiDian District, \\ Beijing 100875, China \\ * Correspondence: make@bnu.edu.cn; Tel.: +86-136-1201-8156
}

Received: 17 January 2019; Accepted: 15 March 2019; Published: 21 March 2019

\begin{abstract}
Globally, acceptance among the general public of waste-to-energy (WtE) incinerators is a crucial factor in implementing national waste-to-energy policies. This study aims to shed light on the acceptance of WtE incinerators, with a focus on anti-incinerator sentiment and the influence and interactions of place-, trust-, and fairness-based factors, with a case study in China. A total of 338 residents in the Asuwei area in North Beijing completed a survey on a proposed WtE incinerator in the vicinity. Hierarchical regression analyses indicate that place attachment positively enhances anti-incinerator sentiment through direct effects, as well as moderation and mediation effects between risk perception and opposing willingness. Furthermore, institutional trust negatively moderates the impact of perceived risk on anti-incinerator sentiment, in addition to directly reducing perceived risk. Trust also influences anti-incinerator sentiment via risk perception, attesting to the effectiveness of a casual model of trust. Likewise, fairness perception acts as another determinant of opposing sentiment, similarly to trust. These findings demonstrate the importance of using a range of instrumental and more effective strategies to promote the acceptance of renewable energy infrastructure.
\end{abstract}

Keywords: social acceptance; anti-incinerator sentiment; place attachment; trust; fairness; waste-to-energy

\section{Introduction}

With rapid economic growth and massive urbanization in China, many metropolises face serious dilemmas regarding municipal solid waste (MSW) disposal. A 2012 World Bank report estimated that by 2025 , more than $11 \%$ of the world's MSW would be generated in China. More than 188.5 million tons of MSW were produced in China in 2016 [1]. Waste-to-energy (WtE) incineration, which recovers energy from discarded MSW and produces electricity and/or steam for heating, is recognized as a renewable source of energy and is the most effective alternative to landfilling, owing to its high efficiency, minimal land requirements, and ability to substantially reduce solid mass [2-4]. Waste incineration is playing an increasingly important role in MSW management and in achieving emissions reduction goals in China [2,5]. According to China's most recent Five-Year Plan (2016-2020), the total investment in waste treatment facilities will amount to 192.4 billion Yuan (about $\$ 30$ billion), almost half of which will be allocated to the construction of new WtE incinerators. In addition, the proportion of WtE incineration will increase from $28.6 \%$ in 2015 to $50 \%$ in 2020 [6]. As of the end of 2017, a total of $339 \mathrm{WtE}$ incinerator projects had been built and put into operation in mainland China, 
with a total installed capacity of 7.253 million kilowatts and annual power generation of 37.52 billion kilowatt hours [7].

However, the siting of WtE facilities has encountered considerable resistance from local communities, with people's concerns stemming largely from the perceived risks to the local landscape, natural environment, economy, and residents' daily lives [8-10]. Social acceptability becomes a decisive factor in the implementation of WtE incineration policies and programs, and thus policy makers and incinerator operators are interested in the public's sentiments regarding the building of WtE incinerators, and in what influences these sentiments. To increase public acceptance of WtE incinerators and other new energy facilities, numerous studies have highlighted the importance of psychological and social factors (e.g., risk and benefit perceptions, affective feelings, and social trust), and provided considerable empirical evidence [4,10-15]. Additional literature has examined socio-psychological factors and how they shape the public's attitudes toward WtE incinerators [15].

In the literature, two persistent approaches are identified $[13,16]$. First, place-based explanations focus on how risky energy facilities alter the emotional connections residents have to their communities. These include the "Not in My Backyard (NIMBY)" concept, place attachment (or sense of place), and place knowledge. The NIMBY explanation has been dismissed by many scholars due to its simplistic way of analysing resistance attitudes, and local opposition is also accepted as a form of place-protective action $[12,13,17]$. Thus, a more universal or novel explanation is needed. Besides the disturbance to natural landscapes, it is widely believed that the presence of energy projects impacts the attachment and identity of local residents to their places [8,18-20]. Given the disturbance, attitudes toward energy projects may become negative or sceptical, even when one has a positive attitude toward renewable technology itself. However, when local change is perceived as an attractive upgrade and as still familiar, it is positively associated with place attachment and promoted an attitude of acceptance [21]. Therefore, place attachment provides an alternative explanation for social acceptance that emphasizes psychological processes, such as meaning making, emotional responses, and action $[12,13]$.

Secondly, trust- and fairness-based explanations highlight the importance of placing trust in planning authorities and operating companies, which plan and approve energy projects. Trust in government and scientists are generally represented by trust in location outcomes and planning procedures in some studies [22,23], and perceptions of outcome fairness and procedural fairness (or justice) in others $[24,25]$.

Studies that have sought to systematically and empirically investigate these combined effects on social acceptance are scarce. Among them, Fast et al. conducted a comparative case study of a wind farm to assess the impact of policy choices on the place-making and trust-building potential of wind projects in the host community [16]. Based on a survey, Devine-Wright suggested that place attachment, perceived impacts, trust in developers, and procedural justice had significant effects on public attitude toward a proposal to construct a high voltage power line [13]. The present research fills a gap in the literature by examining the relationships between perceived risk, place attachment, trust, fairness perception, and anti-incinerator sentiment among inhabitants living near incinerators in China. Section 2 reviews the literature and develops an extended framework for interpreting individuals' opposing sentiments toward incinerators, while Section 3 describes the methodology issues. The final discussion places our findings in the context of the literature and identifies policy implications.

\section{Literature Review and Theoretical Framework}

\subsection{Hypotheses}

\subsubsection{Place Attachment}

As a powerful concept in cultural geography and environmental psychology, "place" refers to a fundamental human trait of creating meaning attached to the spaces we inhabit [26], comprising physical landscapes, social interaction, person and home experiences, and other human activities and 
processes [27]. Disruptions to place-based attachments, identities, meanings, and values can cause crucial emotional responses, because it is "essential to get to the root of ... emotional relationship to place in order to understand people's reasons of blocking or facilitating certain community-based efforts" [28] (p. 340). The core construct, i.e., place attachment, is usually understood as a positive emotional bond between people and prized socio-physical settings over time at different scales, such as homes, neighbourhoods, and cities [29]. These bonds help cultivate group and individual identities [30], a feeling of pride, and a general sense of well-being [31]. However, these links can be disrupted or threatened by diverse forms of change (e.g., landscape transitions, involuntary relocations, and development of large facilities), leading to negative sentiments, such as anxiety, grief, and anger [32,33].

In the context of siting renewable energy projects, such developments physically (re)shape places and socially characterize communities as energy communities. Opposition intention occurs when inhabitants feel that austere external threats may be posed by environmental changes. According to Devine-Wright, the influence of renewable energy infrastructure on natural landscapes can be considered a disruption to place attachment or a threat to place identity, where disruption not only refers to the physical nature, but also to the symbolic and social values of the landscape [12]. In contrast, however, a tidal energy project was found to have strong community support arising from beliefs that it would enhance local distinctiveness by "putting the area on the map worldwide" [34]. Unlike wind farm projects, which can be perceived positively and negatively, incinerator projects are generally considered as threats to the landscape $[11,35]$. The impacts of local energy development on the landscape have been viewed as central to community opposition [36,37]; for instance, an incinerator chimney is typically regarded as a visual perturbation to local landscapes. Furthermore, the threat of renewable projects to landscapes is not only a problem of aesthetics, but also represents a loss of symbolic value; that is, people with strong bonds to their community may view such projects as an “alien invasion" [38] (p. 64). In Petrova's VESPA framework, community concerns were organized into four categories: visual/landscape, environmental, socioeconomic, and procedural [17]. Studies have employed place attachment to describe the value of landscapes in explaining public opposition to disputed projects $[12,38]$. Jasper described the emotions of protest as a continuum from "long term" effects (e.g., love of rural landscape, "fondness for neighbourhood," or ongoing loyalty to place) to immediate reactions [39].

Research has shown that place attachment influences residents' attitudes and behavioural intentions toward local change caused by energy projects [18-20,40]. Individuals who hold strong place attachment and a more positive sense of identity from particular rural landscapes are more likely to feel threatened and take part in oppositional behaviour [12,13,18,41]. However, Devine-Wright also found the opposite to be true, showing that place attachment emerged as a positive predictor of project acceptance in a tidal energy case study, affirming its value in explaining public response [19]. As for the relationship between place attachment and risk perception, Venables et al. reported that attachment offers a feeling of safety and leads to a neglect of nuclear power risk [14]. More generally, Bernardo summarized that place attachment may contribute to amplifying high probability risk perceptions (less dangerous, but more frequent), while attenuating the perception of low probability risks (often most dangerous, e.g., nuclear accidents) [42]. Such evidence leads us to develop the following hypotheses:

Anti-incinerator sentiment toward a community WtE incinerator is a function of the interaction between the perceived risk and place attachment to the dwelling community. Specifically:

Hypothesis 1. People with higher place attachment have a higher level of anti-incinerator sentiment.

Hypothesis 2. People with higher risk perception have a higher place attachment to a dwelling community.

Hypothesis 3. People with higher place attachment have a higher risk perception toward a community WtE incinerator. 
In the setting of natural disasters, moderating and mediating effects exerted by place attachment are found between risk perception and coping behavioural responses. For example, based on empirical studies in two Italian cities exposed to flood risk, De Dominicis et al. found that place attachment negatively moderated the connection between risk perception and preventive coping behaviours [43]. Venables and colleagues suggested that sense of place mediated (but did not moderate) the relationship between the proximity and risk perception for renewable energy projects [14]. Lima et al. found that place identity acted as a statistical moderator in the relationship between proximity and local people's perceptions of risk in relation to the siting of a new incinerator [44]. However, for controversial energy facilities, this moderating or mediating effect between risk perception-coping sentiment has not been sufficiently investigated. Therefore, further investigation must explore how place attachment affects the connection between risk perception and opposing (or acceptance) sentiment relative to WtE sitings.

Hypothesis 4. Place attachment moderates the effect of risk perception on anti-incinerator sentiment toward a community WtE incinerator. Specifically, place attachment increases the positive effect exerted by perceived risk on anti-incinerator sentiment.

Hypothesis 5. Place attachment mediates the connection of risk perception and anti-incinerator sentiment toward a community WtE incinerator.

Moreover, we cannot be certain whether risk perception acts as a mediator between place attachment and anti-incinerator sentiment. Further, we assume that:

Hypothesis 6. Risk perception mediates the connection between place attachment and anti-incinerator sentiment.

\subsubsection{Trust and Fairness}

A community's acceptance or opposition attitude is also a question of fairness and trust. Trust is conceptualized and studied in different literature, such as in management, organizational behaviour, and political science. This term is also a key concept in the literature on the sociology of technology, and "acts as a substitute for knowledge in complex societies characterized by risk" [45] (p. 3). As "a psychological state comprising the intention to accept vulnerability based upon positive expectations of the intentions or behaviour of another" [46] (p. 395), trust means "a willingness to rely on those who have the responsibility for making decisions and taking actions related to the management of technology and policy implementation" [47,48] (p. 447). It serves as an indispensable catalyst for satisfying cooperation of diversified actors striving to solve controversial problems [49] and is "essential for the capacity of social-ecological systems to adapt to and shape change" [50] (p. 261).

The multidimensionality of trust has been presented in selective configurations. Based on extant research, Fulmer et al. distinguished between trust at a level and trust in a referent. Three organizational levels-individual, team, and organizational-and three referents-interpersonal, team, and organization-were elaborated upon [51]. In the context of siting controversial energy projects, trust generally denotes an individual's degree of trust in varied organizational entities, such as operating enterprises, regulatory authorities, and academic circles in incineration area. In two case studies of power line development, Ceglarz et al. developed a conceptual meaning of three dimensions of trust-interpersonal, social, and institutional-and underpinned the importance of all of these dimensions in conducting public engagement processes [49]. Additionally, Mah et al. proposed three dimensions of trust: trust in motives (integrity, care, and fairness), trust in transparency (openness), and trust in competency (credibility, competence, and reliability), within the context of nuclear power [52]. For our research, we focus on institutional trust, that is, the level of an individual's trust in authorities from regulatory governments and operating enterprises, and experts and scholars in the incinerator field. 
There is substantial empirical evidence that institutional trust interacts with risk perception and acceptance of local negative changes $[4,53,54]$. The degree to which host community members trust the siting process and the wider policy decisions to advance renewable energy programs is of extreme importance to promote the implementation of renewable energy policy $[16,55]$. In nuclear energy decision-making, distrust in key decision-makers in relation to the dimensions of motives, transparency, and competence is one of the major factors that explains high risk perception and opposition to nuclear energy [52]. In the Chinese mainland, when unfamiliar with nuclear power stations, people are inclined to perceive the benefits and risks through emotional identification and social trust, rather than rational deduction [56]. Specific to the siting of WtE incinerators, trust in authorities (local government and operators) is found to positively associate with public acceptance, both directly and indirectly, through risk perception, and promoting public trust can enhance public acceptance more efficiently than reducing perceived risk [4,57]. Drawing upon these findings, we hypothesize the following:

Hypothesis 7. Institutional trust negatively predicts anti-incinerator sentiment toward a community incinerator.

Hypothesis 8. Institutional trust negatively influences perceived risk.

Although it is widely recognized that acceptance, trust, and risk perception often interact, there is still considerable disagreement about the underlying patterns of causality among the constructs. As the casual model of trust (CMT) indicates, trust affects technology acceptance through risk perceptions or benefits. In a cross-cultural investigation of 23 activities and technological hazards, trust in regulatory organizations is found to be directly and indirectly linked with public acceptance, and perceived benefit plays a more important role than perceived risk in mediating the trust-acceptability casual chain [58]. Regarding nuclear power plants (NPPs), goodwill trust improves acceptance of NPPs by decreasing risk perception, while competence trust improves the acceptance by increasing benefit perception [59]. However, these findings are challenged by the associationist model of trust (AMT), which asserts that acceptance drives both trust and risk perception [60,61]. For example, Boecker et al. found that risk perception was a precondition for trust playing a role in decision making, and there was no empirical evidence to show that the impact of trust on acceptance was mediated through risk perception [62]. Rather than being a determinant, trust in government regulation is an expression or indication of the acceptability of genetically modified food, and specific risk judgments are driven by more general evaluative judgments, termed "affect" by Poortinga et al. [63]. Considering the conflicting results, it is necessary to discuss which model is supported in explaining the trust-acceptance relationship in Chinese WtE contexts.

Additionally, within the context of community energy projects, (generalized) trust is found to positively predict the willingness to participate and moderates the effect of community identity on the willingness to participate in a local community energy project [64]. Therefore, in addition to the direct effect of trust on resistant sentiments, we propose an interaction of trust with perceived risk and place attachment. We expect that risk perception or place attachment has a positive association with residents' anti-incinerator sentiment through changes in trust, and propose the following hypotheses:

Hypothesis 9. Trust moderates the positive effect of perceived risk on the anti-incinerator sentiment toward a local incinerator. Specifically, when people have a higher degree of trust, the positive impact of perceived risk on anti-incinerator sentiment will be diminished, to some extent.

Hypothesis 10. Trust moderates the positive effect of place attachment on anti-incinerator sentiment toward a local incinerator. Specifically, when people have higher degree of trust, even higher place attachment will not significantly increase the intention to resist an incinerator located in their community. 
We also assume that risk perception mediates the linkage between trust and anti-incinerator sentiment, in order to test whether the CMT model is supported. The relationship between trust and general attitude is also the interest of our paper. Thus, two additional hypotheses are proposed:

Hypothesis 11. Risk perception mediates the connection between trust and anti-incinerator sentiment.

Hypothesis 12. Trust positively influences the general attitude (intention to accept WtE technology).

Distrust is associated with feelings of being treated unfairly or unjustly, which is another emotional cause for oppositional activism, and in this respect, it can be represented in terms of perceived fairness or justice, including perceptions of both procedural (how decisions are made) and distributional (who gets what) justice $[38,65]$. Perceived procedural fairness/justice is a subjective assessment of participative and deliberative fora and mechanisms of public engagement [66], including several issues, such as timing, transparency, and equity (for a detailed discussion, see Goedkoop et al. [23]). Distributional fairness/justice is about how costs, risks, and benefits are distributed [36]. A fair settlement plan and transparency in the implementation of the compensation plan are conducive to lessening the interest conflicts [9]. Therefore, the perception of fairness/justice, as emphasized by Wolsink [36] and Wester-Herber [8], is another issue of importance in incinerator siting. Hall et al. asserted that distributional justice and procedural justice could foster trust and reduce opposition to energy projects [24]. As stated by Huijts et al., judgments of fairness led to trust and vice versa [67]. Although fairness research has uncovered important findings, it remains unclear whether the effect of risk perception on opposing sentiment is moderated by fairness perception, and whether fairness perception impacts resistance intention through risk perception. Thus, we will further explore the connections between these constructs with respect to incinerator sitings in Chinese society, and the following related hypotheses are suggested:

Hypothesis 13. Fairness perception can reduce anti-incinerator sentiment.

Hypothesis 14. Fairness perception can reduce perceived risk toward a local WtE incinerator.

Hypothesis 15. Fairness perception positively predicts institutional trust in the authorities operating and regulating a WtE incinerator.

Hypothesis 16. The effect of risk perception on anti-incinerator sentiment is moderated by fairness perception.

Hypothesis 17. Risk perception mediates the connection between fairness perception and anti-incinerator sentiment.

We also hope to understand the role of general attitude in predicting anti-incinerator sentiment, and which fairness perception is more important in predicting accepting attitude. Hence, the last two hypotheses are assumed.

Hypothesis 18. General attitude toward WtE incineration negatively influences anti-incinerator sentiment toward a community incinerator.

Hypothesis 19. Distributional fairness perception is more important than procedural fairness perception in predicting anti-incinerator sentiment.

\subsection{Theoretical Framework}

Based on an extant socio-psychological model and empirical studies on renewable energy projects, an extended model is developed to investigate the effects of psychological-emotional factors on 
the public's acceptance of WtE incinerators in China's metropolitan settings. Figure 1 shows the hypothesized conceptual model. We integrate place-based and trust-based factors into a model of residents' attitudes toward WtE incinerator development. In this model, perceived risk, place attachment, trust, and perceived fairness are exogenous variables, and attitude toward WtE incinerators is an endogenous variable.

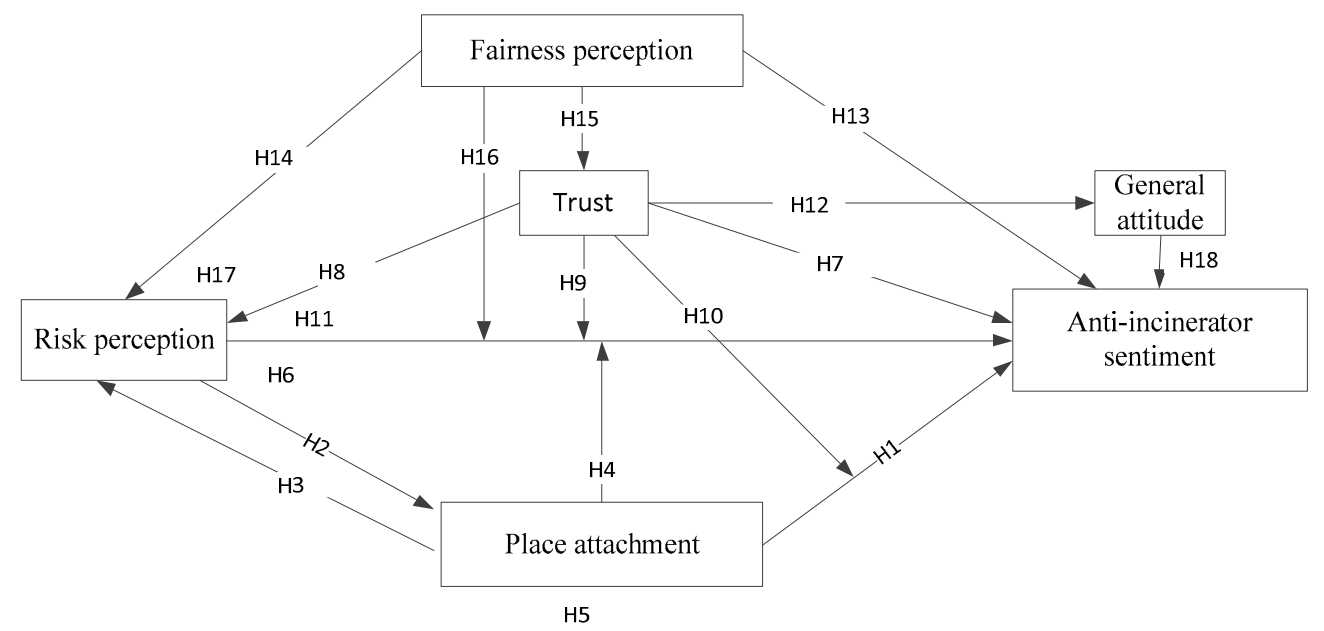

Figure 1. Conceptual model of the study.

\section{Materials and Methods}

\subsection{WtE Incinerator Project and Local Context}

The Asuwei (meaning "defense" in Mongolian) area is located in Xiaotangshan in the Changping District of Beijing and includes several villages (e.g., Asuwei, Erde Zhuang, Niufangjuan, and Baishan) and upscale villa communities (e.g., Baolilongshang, Panaxigu, and Jujun). According to the three-year (2013-2015) implementation plan for the construction of municipal solid waste treatment facilities in Beijing [68], the Asuwei WtE incinerator was planned to be placed into operation by the end of 2017, at which time it was estimated that approximately 3000 tons of domestic garbage would be disposed of every day, and the annual power generation would reach 350 million kilowatt hours, of which $70 \%$ would be integrated into power distribution networks. Since being informed of plans for the Asuwei WtE incinerator, villagers and residents have expressed their complaints in various ways, including signing a petition against the building of incinerator, petitioning government departments, and participating in demonstrations and other protests.

\subsection{Procedure and Respondents}

From May-July 2016, a survey was conducted in the Asuwei area. To approach a heterogeneous sample, a stratified sampling method was used. First, according to differences in the mode of production, lifestyle, and administrative pattern, the communities surveyed were divided into rural and urban communities, with the former including the villages of Asuwei, Baishan, and Niufangjuan, and the latter including Baolilongshang and Tang House. Second, 100 questionnaires were distributed door-to-door by local fieldworkers in each community. A total of 500 copies were distributed, and 338 respondents (67.6\% response rate) returned a completed survey, with male and female participants ranging in age from 19 to 72 years (Mean $=45.2$, Standard deviation $=12.7$ ). Overall, the participants have lived in the area for an average of 22.3 years (Standard deviation $=19.7$, range: 3-67) and reported an average of approximately 110,000 Yuan in annual household income (Standard deviation $=166,000$, Range $=20,000-220,000$ ). Table 1 provides an overview of the sample characteristics. 
Table 1. Sample demographics $(N=338)$.

\begin{tabular}{cccccccc}
\hline Variable & Group & Frequency & $\begin{array}{c}\text { Percentage } \\
\mathbf{( \% )}\end{array}$ & Variable & Group & Frequency & $\begin{array}{c}\text { Percentage } \\
\mathbf{( \% )}\end{array}$ \\
\hline \multirow{2}{*}{ Gender } & Male & 180 & 53.3 & & $<50 \mathrm{k}(\mathrm{RMB})$ & 132 & 39.1 \\
& Female & 158 & 46.7 & Average annual & $60 \mathrm{k}-100 \mathrm{k}$ & 61 & 18.0 \\
& $18-30$ & 47 & 13.9 & household income & $110 \mathrm{k}-200 \mathrm{k}$ & 103 & 30.5 \\
\multirow{2}{*}{ Age } & $31-40$ & 89 & 26.3 & & $210 \mathrm{k}-300 \mathrm{k}$ & 33 & 9.8 \\
& $41-50$ & 92 & 27.2 & & $>310 \mathrm{k}$ & 10 & 3.0 \\
& $51-60$ & 77 & 22.8 & & $<10$ (years) & 143 & 42.3 \\
& $>61$ & 33 & 9.8 & & $11-20$ & 76 & 22.5 \\
\multirow{2}{*}{ Educational level } & Primary & 91 & 26.9 & Dwelling time & $21-30$ & 41 & 12.5 \\
& Secondary & 158 & 46.7 & & $31-40$ & 20 & 5.9 \\
& Higher & 89 & 26.3 & & $41-50$ & 22 & 6.5 \\
\multirow{2}{*}{ Home-ownership } & Renter & 76 & 22.5 & & $51-60$ & 25 & 7.4 \\
& Owner & 262 & 77.5 & & $>60$ & 11 & 3.3 \\
\hline Community type & Urban & 170 & 50.3 & & Rural & 168 & 49.7 \\
\hline
\end{tabular}

\subsection{Measures}

A 34-item questionnaire was designed following reviewed literature to evaluate: (1) respondents' resistant sentiment toward the WtE incinerator in a dwelling community; (2) respondents' perceptions of risk and place attachment to the dwelling community; (3) respondents' institutional trust levels in key actors, namely academics/experts, operators, and regulatory agencies, and perceptions of fairness, including procedural fairness and distributive fairness; and (4) respondents' socio-demographic characteristics. A seven-point Likert scale $(1=$ strongly disagree, $4=$ neutral/undecided, and 7 = strongly agree) was used to rate the above constructs. The measures for each construct are presented as follows:

General attitude (GA). Three items (Cronbach's $\alpha=0.91$ ) measuring residents' attitude toward $\mathrm{WtE}$ industry or technology were adapted from previous studies [15]. The items are: "I think WtE incineration is necessary to dispose MSW" (GA1), "I accept incinerators in my city" (GA2), and "I am not in favour of developing WtE incinerators as a form of disposing garbage" (GA3).

Anti-incinerator sentiment (AS). First, we adopted an item to identify the basic intention, which is "I am willing to oppose the construction of a WtE incinerator in my community". Then, four items were adapted from De Groot et al. [69] and Prati et al. [70] to measure anti-incinerator sentiments (Cronbach's $\alpha=0.86$ ). Respondents were asked "If you are willing to oppose the construction of an incinerator, will you assume the following kinds of behavior?" The four kinds of actions comprised expressing opinions against the building of incinerators (AS1), signing the petition against the building of incinerators (AS2), petitioning government departments (AS3), and participating in demonstrations and other protests (AS4). We averaged scores, and higher numbers indicated higher anti-incinerator sentiment.

Perceived risk (PR). To assess risk perception of a WtE incinerator, a three-item scale (Cronbach's $\alpha=0.76$ ) was used, adapted from Brewer et al.'s meta-analysis of risk, including perceived likelihood, perceived susceptibility, and perceived severity [71]. They are: "It is likely that I could get sick from the proposed incinerator" (PR1), "I get sick more easily than before the incinerator was built" (PR2), and "Pollution from the incinerator can cause cancer and even death" (PR3). These items predominantly measured perceived health risks, because our interview results showed that health risks comprised the primary concerns and complaints of residents regarding WtE incinerator plants.

Place attachment (PA). Place attachment was commonly examined at three levels: homes, neighbourhoods, and cities. In analysis of the threats concentrated within the Asuwei community, PA was measured as neighbourhood attachment and we used a four-item scale (Cronbach's $\alpha=0.89$ ) borrowed from Fornara et al., which measured integration, identity, and rootedness toward the neighbourhood of residence [72]. Fornara et al.'s scale has been employed in several studies that assess urban change and environmental risk (e.g., von Wirth et al. [21]; De Dominicis et al., [43]). 
The items are: "This neighbourhood is part of me" (PA1), "It would be very hard for me to leave this neighbourhood" (PA2), "This is the ideal neighbourhood for me" (PA3), and "I do not feel integrated in this neighbourhood" (PA4).

Institutional trust (IT). A list of organizations and institutions was read to participants, and they were asked how much trust they had in motives, transparency, and competency. These entities were divided into three groups: industry, government, and community of scientists. Incinerator industry trust (IIT) refers to trust in operators of incinerators, governmental trust (GT) consists of trust in incinerator regulatory authorities, such as the Environmental Protection Agency and City Administration Bureau. Academics/experts trust (AT) indicates trust in scientists and engineers working in incineration related fields. The items (Cronbach's $\alpha=0.95)$ adapted from Mah et al. [50] are: "I trust in operators of incinerators" (T1), "I trust in scientists and engineers in incineration areas" (T2), "I trust in incinerator regulatory authorities, such as the Environmental Protection Agency" (T3). Together, the three items formed an internally consistent scale (Cronbach's $\alpha=0.821$ ).

Fairness perception (FP). Two dimensions of justice as it relates to the location of energy facilities are procedural justice and distributional justice [73]. Based on the work of Tyler [74] and King et al. [75], a seven-item procedural justice scale (Cronbach's $\alpha=0.95)$ was used to measure four aspects of procedural fairness perception: voice, respect, trustworthiness, and fairness. Distributive justice in this study was measured via a two-item scale (Cronbach's $\alpha=0.86$ ) borrowed from Visschers et al. [55]. The items focused on the fairness of decision in general and on the costs and benefits for the local communities, which included "The financial compensations (e.g., tax payments of operators) counterbalance the disadvantages (e.g., accident risks and environmental pollution)" and "The wishes of the population at that site are sufficiently considered at the site selection of WtE incinerators".

\subsection{Data Analysis}

To test the hypotheses, considering the relatively limited sample size, hierarchical multiple regression analyses (HMRA) and moderation and mediation analyses were performed using IBM SPSS version 21 and its PROCESS procedures [76,77]. HMRA was widely used for detecting the interaction effects of social-psychological constructs (e.g., De Dominicis et al. [43], and von Wirth et al. [21]).

Our study is divided into three sections: (i) interactions between risk perception, place attachment, and anti-incinerator sentiment; (ii) interactions between risk perception, trust, and anti-incinerator sentiment; and (iii) connections between risk perception, fairness perception, and anti-incinerator sentiment.

\section{Results}

\subsection{Descriptive Statistics}

As Table 2 and Figure 2 show, first, residents' general attitudes about WtE incineration as a means of disposing MSW are positive although anti-incinerator sentiment is slightly higher. Expressing opinions against incinerators is the most preferred form of protest, while participating in protests is the least preferred form of protest. Second, the data show higher levels of risk perception and place attachment than general attitude and anti-incinerator sentiment. The respondents report a subaverage level of institutional trust and fairness perception, especially about trust in operators and distributive fairness. 
Table 2. Overview of main constructs.

\begin{tabular}{llllll}
\hline Measures (N = 338) & Mean & SD & Measures & Mean & SD \\
\hline General attitude (GA) & 4.46 & 1.17 & Place attachment (PA) & 4.82 & 4.77 \\
GA1 (necessity) & 4.46 & 1.05 & PA1 (integration) & 4.58 & 1.07 \\
GA2 (acceptance in one's city) & 4.38 & 1.25 & PA2 (identity) & 4.90 & 5.00 \\
GA3 (technological acceptance) & 4.55 & 1.48 & PA3 (rootedness) & - & 1.27 \\
Anti-incinerator sentiment (AS) & 4.86 & 1.24 & PA4 (integration) & 3.68 & 1.13 \\
AS1 (express opinions) & 5.28 & 1.22 & - & 4.08 & 1.46 \\
AS2 (sign petitions) & 4.88 & 1.25 & Institutional trust & 3.09 & 1.45 \\
AS3 (petition the gov.) & 4.65 & 1.25 & IT1 (Trust in academics) & 1.48 \\
AS4 (participate in protests) & 4.20 & 1.09 & IT2 (Trust in operators) & 1.66 \\
Perceived risk (PR) & 4.95 & 0.81 & IT3 (Trust in regulatory agencies) & 3.87 & 3.64 \\
PR1 (perceived likelihood) & 5.02 & 1.00 & Fairness perception (FP) & 3.79 & 1.26 \\
PR2 (perceived susceptibility) & 4.98 & 0.97 & Procedural fairness & 3.50 \\
PR3 (perceived severity) & 4.85 & 1.01 & Distributive fairness & 1.60 \\
\hline
\end{tabular}

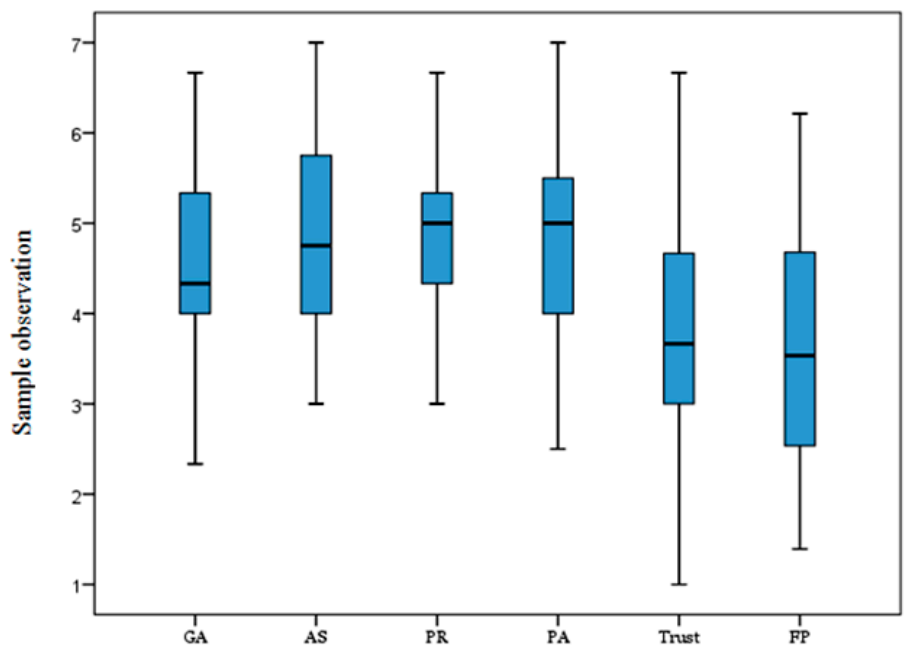

(a)

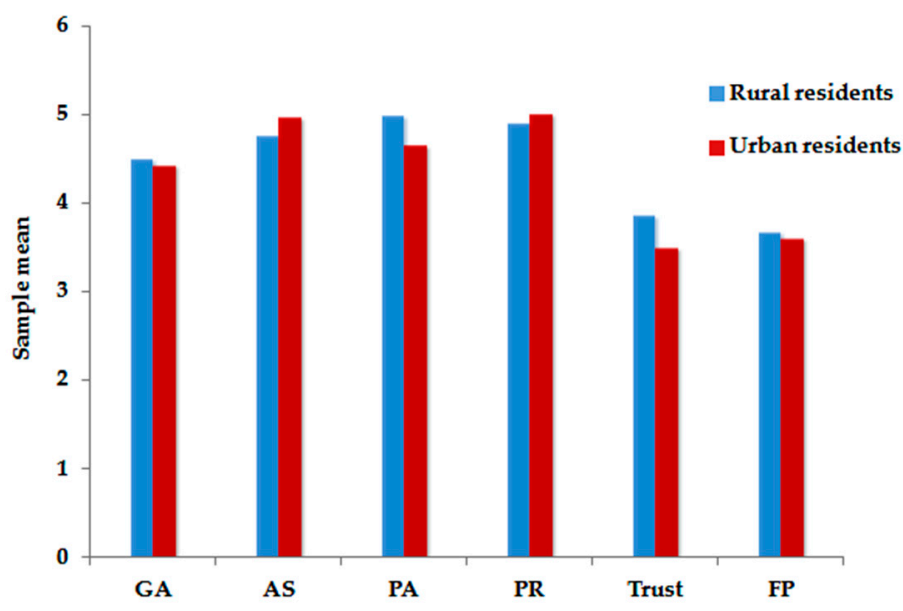

(b)

Figure 2. (a) Box plot of main constructs; (b) Comparison of group arithmetic means. Note: GA: General attitude, AS: Anti-incinerator sentiment, PA: Place attachment, PR: Perceived risk, FP: Fairness perception.

We analysed whether rural and urban residents hold different perceptions and attitudes toward the community WtE incinerator and their dwelling place. As shown in Figure $2 b$, for the six variables, a comparison of group arithmetic means indicates nearly equal levels, and according to Levene's test, the assumptions of homogeneity of variance for all constructs are not rejected (all $p>0.05, \mathrm{~F}<3.03)$. 
Thus, using an independent sample $t$ test to compare the intergroup differences, we find that all other main constructs are not significantly different, excepting place attachment $(t(335)=2.92, p=0.004$, $95 \%$ CI $[0.11,0.56])$ and trust $(t(336)=230, p=0.022,95 \%$ CI $[0.05,0.67])$. In addition, the magnitude of difference in the mean is negligible. Thus, we integrated the two groups of data and further investigated their characteristics and inner casual relationships.

\subsection{Correlation Analysis}

Correlations between the variables of interest are shown in Table 3. General attitude shows a moderate negative relationship with anti-incinerator sentiment; perceived risk, by contrast, shows a positive relationship with trust and fairness perception. There is a slightly stronger correlation between anti-incinerator sentiment and risk perception, along with trust and fairness perception, with which the relationships are negative. Hence, we also find a positive association between perceived risk and place attachment, and relatively higher and negative linkages of the former with trust and fairness. Finally, trust presents a slightly stronger positive connection with fairness, as expected.

Table 3. Constructs' partial correlations.

\begin{tabular}{ccccccc}
\hline Construct & GA & AI & PR & PA & Trust & FP \\
\hline General attitude & 1 & & & & & \\
Anti-incinerator sentiment & $-0.34^{* * *}$ & 1 & & & & \\
Perceived risk & $-0.46^{* * *}$ & $0.64^{* * *}$ & 1 & & & \\
Place attachment & $-0.19^{*}$ & $0.26^{* * *}$ & $0.49^{* *}$ & 1 & & \\
Trust & $0.39^{* * *}$ & $-0.66^{* *}$ & $-0.56^{* *}$ & $-0.30^{*}$ & 1 & 1 \\
Fairness perception & $0.37^{* * *}$ & $-0.57^{* * *}$ & $-0.63^{*}$ & $-0.27^{* *}$ & $0.59^{* * *}$ & 1 \\
\hline
\end{tabular}

Note: ${ }^{* *} p<0.001,{ }^{* *} p<0.01,{ }^{*} p<0.05$; Control: age, educational level, gender, homeownership, community style, household income, and dwelling time. GA: general attitude, AI: anti-incinerator sentiment, PR: perceived risk, PA: place attachment, FP: fairness perception.

\subsection{Regression Analysis 1: Risk Perception, Place Attachment, and Anti-Incinerator Sentiment}

To avoid multicollinearity problems among predictor variables, the authors examined the correlation matrix and avoided using two variables with correlation coefficients higher than 0.5 in the same model (e.g., risk perception and trust and fairness perception) [78]. All the Durbin-Watson test values of the regression models listed on in Tables 4-10 are between $0 \sim 4$, indicating that the observed values of the multiple linear regression are mutually independent. Moreover, the tolerances of all the variables are greater than 0.1, and the Variance Inflation Factors (VIF) are less than 10, suggesting that multicollinearity is not a serious problem.

Given that the present research predicts relatively complicated causal relationships, with the exception of hierarchical regression analysis, the PROCESS procedure in SPSS is adopted to examine the hypotheses in the conceptual framework (see Figure 1) for its prominent advantages by centring all predictors automatically, computing the interaction terms, and providing simple slop analysis results (see Field [79] for a detailed discussion).

As shown in Table 4, Model 2 indicates that perceived risk is a significant (positive) predictor of place attachment toward a dwelling community $(\beta=0.42, t=10.19, p<0.001)$, explaining some amount of the variance in place attachment $\left(\Delta R^{2}=0.16, \Delta F=104.22, p<0.001\right)$, supporting the $\mathrm{H} 2$. In Model 4, place attachment is significantly positive $(\beta=0.57, t=10.19, p<0.001)$ in predicting perceived risk with some explanatory power $\left(\Delta R^{2}=0.21, \Delta F=104.22, p<0.001\right)$. Thus H 3 is confirmed. Therefore, place attachment and risk perception are inseparable and promote one another, implying possible mutual mediating effects. In Models 5 and 6, we find that the regression coefficients of trust and fairness perception are both significantly negative on predicting perceived risk, which supports $\mathrm{H} 8$ and $\mathrm{H} 14$. Again, these results suggest a possible mediation effect of risk perception between trust (or fairness perception) and anti-incinerator sentiment. These results are in line with the conclusions drawn from most of the reviewed literature. 
Table 4. Hierarchical regression of place attachment and risk perception.

\begin{tabular}{|c|c|c|c|c|c|c|}
\hline & Model 1 & Model 2 & Model 3 & Model 4 & Model 5 & Model 6 \\
\hline Variables & PA & PA & PR & PR & PR & PR \\
\hline Educational level ${ }^{a}$ & & & $0.14 *$ & $0.15^{*}$ & $0.13 *$ & $0.12 *$ \\
\hline Homeownership ${ }^{b}$ & $0.42 * * *$ & $0.33^{* * *}$ & $0.24^{* * *}$ & & & \\
\hline Dwelling time & $0.27^{* * *}$ & $0.21 * *$ & $0.15^{*}$ & & & $0.08 *$ \\
\hline Perceived risk & & $0.42^{* * *}$ & & & & \\
\hline Place attachment & & & & $0.57^{* * *}$ & & \\
\hline Trust & & & & & $-0.33^{* * *}$ & \\
\hline Fairness perception & & & & & & $-0.39 * * *$ \\
\hline Adjusted $\mathrm{R}^{2}$ & 0.34 & 0.50 & 0.10 & 0.315 & 0.38 & 0.47 \\
\hline $\mathrm{F}$ & $25.83 * * *$ & $42.72 * * *$ & $6.34 * * *$ & $20.31^{* * *}$ & $26.44^{* * *}$ & $36.40 * * *$ \\
\hline$\Delta \mathrm{R}^{2}$ & 0.36 & 0.16 & 0.12 & $0.21^{\mathrm{c}}$ & $0.28^{\mathrm{d}}$ & $0.35^{\mathrm{e}}$ \\
\hline$\Delta \mathrm{F}$ & $25.83^{* * *}$ & $104.22 * * *$ & $6.23 * * *$ & $104.22 * * * c$ & $148.40^{* * * d}$ & $218.79 * * \mathrm{e}$ \\
\hline
\end{tabular}

Note. ${ }^{*} p<0.05 ; * * p<0.01 ; * * *<0.001 ; \beta=$ standardized coefficients; only significant coefficients are presented. PA: place attachment, PR: perceived risk; ${ }^{a}$ Dummy variable for holding bachelor's degree or higher; ${ }^{b}$ Dummy variable for renting tenant (vs. being owner); ${ }^{c, d, e}$ are all relative to Model 3.

To test the interaction effect of perceived risk and place attachment on predicting anti-incinerator sentiment, the PROCESS procedure was used. As shown in Table 5, analysis reveals a significant (positive) main effect of risk perception $(\beta=0.59,95 \% \mathrm{CI}[0.52,0.65], t=17.89, p<0.001)$, consistent with prevailing views; this suggests that high perceived risk promotes anti-incinerator sentiment. There is also a significant and positive effect of place attachment $(\beta=0.66,95 \%$ CI [0.59, 0.74], $t=17.19$, $p<0.001)$, supporting H1. More importantly, there is a significant interaction effect $(\beta=-0.12$, $95 \%$ CI $[-0.17,-0.06], t=-4.43, p<0.001)$, indicating that place attachment negatively moderates the relationship between perceived risk and anti-incinerator sentiment (conditional effect of $X$ on $Y=0.59-0.12 \mathrm{M})$, which supports $\mathrm{H} 4$.

Table 5. Risk perception, place attachment, and anti-incinerator sentiment.

\begin{tabular}{|c|c|c|c|c|c|c|c|}
\hline \multirow{2}{*}{ Model } & $R-s q$ & $R^{2}$-chng & $F$ & Sig. & $\beta$ & $t$ & $p$ \\
\hline & 0.50 & & 32.06 & 0.000 & & & \\
\hline Constant & & & & & 4.923 & 162.109 & 0.000 \\
\hline Perceived risk (standardized) & & & & & 0.586 & 17.889 & 0.000 \\
\hline Place attachment (standardized) & & & & & 0.661 & 17.189 & 0.000 \\
\hline $\mathrm{PR} * \mathrm{PA}$ & & 0.009 & 19.594 & 0.000 & -0.116 & -4.427 & 0.000 \\
\hline
\end{tabular}

Note: Control = Z-age, Z-educational level, Z-gender, Z-homeownership, Z-community type, Z-household income,

Z-dwelling time.

To further clarify the two-way interaction, spotlight analysis was conducted at one standard deviation above and below the mean place attachment using the procedure by Aiken et al. [80]. The result (see Figure 3) reveals that when residents maintain higher attachment to their dwelling place, there is a significant (positive) but slightly weaker relationship between perceived risk and anti-incinerator sentiment $(\beta=0.47,95 \%$ CI $[0.39,055], t=11.30, p<0.001)$. Similarly, when lower place attachment is perceived by residents, there is also a significant (positive) and a slightly stronger relationship between perceived risk and anti-incinerator sentiment $(\beta=0.70,95 \% \mathrm{CI}$ $[0.62,0.78], t=16.63, p<0.001)$. This indicates that a high level of attachment increases awareness of anti-incinerator sentiment, regardless of risk perception, and in the case of lower attachment, the anti-incinerator willingness will be constrained to a lower degree, although it rises faster. 


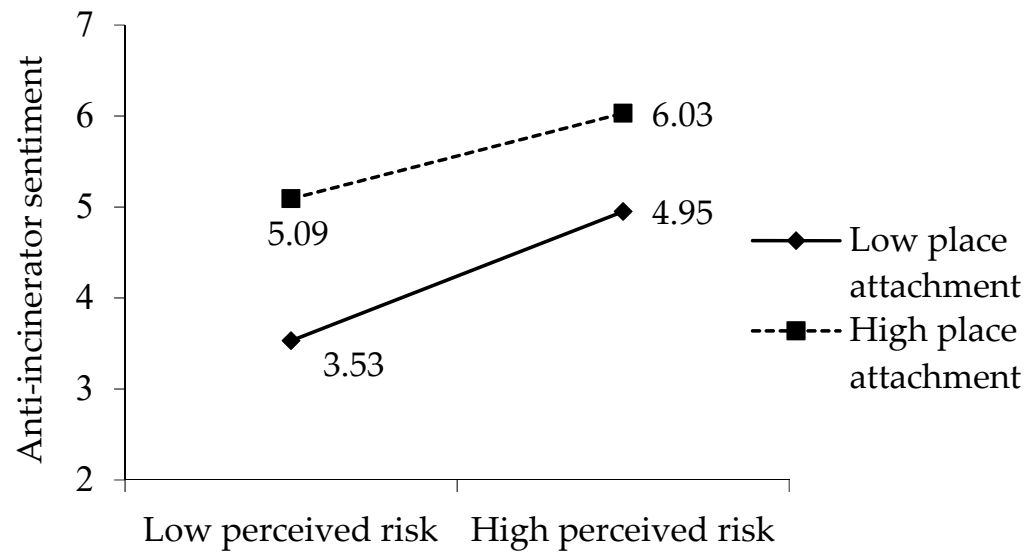

Figure 3. Interaction of perceived risk and place attachment.

Next, we test $\mathrm{H} 5$ and $\mathrm{H}$ 6. Because $\mathrm{H} 1$ and $\mathrm{H} 2$ have been confirmed ( $a$ and $b$ are both significant, see Table 6), we expect that there is a mediating effect presented by place attachment between risk perception and anti-incinerator sentiment. Thus, the bootstrap method and PROCESS Procedure for SPSS are employed to test the interaction of the independent variable (perceived risk) and mediating variable (place attachment), and we find that the direct effect $\left(c^{\prime}\right)$ of risk perception and anti-incinerator sentiment is significant $(\beta=0.584, S E=0.035,95 \% \mathrm{CI}[0.532,0.663], t=2.684, p=0.0076)$, and more importantly, the indirect effect $\left(a^{*} b\right)$ is proved (effect $=0.272, S E=0.032,95 \% \mathrm{CI}[0.204,0.329], p<0.001$ ). Thus, H 5 is supported.

Table 6. Mediation effect of place attachment.

\begin{tabular}{|c|c|c|c|c|c|c|c|c|}
\hline \multirow[t]{2}{*}{ Panel 1: } & \multicolumn{4}{|c|}{ Mediator (Place Attachment) } & \multicolumn{4}{|c|}{ Anti-Incinerator Sentiment } \\
\hline & & Coeff. & $S E$ & $p$ & & Coeff. & $S E$ & $p$ \\
\hline Perceived risk & $a$ & 0.419 & 0.041 & 0.000 & $c^{\prime}$ & 0.584 & 0.035 & 0.000 \\
\hline Place attachment & - & - & - & - & $b$ & 0.649 & 0.039 & 0.000 \\
\hline Constant & & -0.002 & 0.386 & 0.967 & & 4.859 & 0.027 & 0.000 \\
\hline \multirow[t]{2}{*}{ Panel 2: } & \multicolumn{4}{|c|}{ Sobel Test $\left(a^{*} b\right)$} & \multicolumn{4}{|c|}{ 95\% Confidence Intervals } \\
\hline & Value & $S E$ & $t$ & $p$ & & & & \\
\hline Direct effect & 0.584 & 0.034 & 17.343 & 0.000 & & & & \\
\hline Indirect effect & 0.272 & 0.032 & - & - & & & & \\
\hline
\end{tabular}

Similarly, we tested the possible mediation effect of risk perception between place attachment and anti-incinerator sentiment. It was found that the direct effect $\left(c^{\prime}\right)$ of place attachment and anti-incinerator sentiment was not significant $(\beta=-0.101, S E=0.061,95 \%$ CI $[-0.220,0.018]$, $t=-1.667, p=0.096)$, but the indirect effect $\left(a^{*} b\right)$ was proved (effect $=0.422, S E=0.049,95 \% \mathrm{CI}$ $[0.325,0.519], p<0.001)$, supporting H 6. In summary, the hypothesized mediation effects of place attachment and risk perception are acknowledged, and risk perception appears a have a higher magnitude on mediation effect than place attachment.

\subsection{Regression Analysis 2: Trust, Fairness, General Attitude, and Anti-Incinerator Sentiment}

Then, we added institutional trust, fairness perception, and general attitude to our analysis models. For the main effect tests, as shown in Table 7, Models 2-4 indicate that trust, fairness perception, and general attitude all negatively predict anti-incinerator sentiment, and trust provides more explanatory power than the other two variables $\left(\beta=-0.55, \Delta R^{2}=0.39, \Delta F=253.75, p<0.001\right)$. Hence, our findings provide support for $\mathrm{H} 7, \mathrm{H} 13$, and $\mathrm{H} 18$. Thus, the greater the amount of trust in authorities, perceived fairness, and more open and inclusive attitudes to WtE incineration (including industry and technology), the less likely one is to object to an incinerator located in the community. 
Table 7. Hierarchical regression of anti-incinerator sentiment.

\begin{tabular}{|c|c|c|c|c|}
\hline & Model 1 & Model 2 & Model 3 & Model 4 \\
\hline Variables & AI & AI & AI & AI \\
\hline Gender $^{a}$ & & & $-0.22 *$ & \\
\hline Homeownership & $0.73^{* * *}$ & & $0.49 * *$ & $0.53 * *$ \\
\hline Community type ${ }^{b}$ & $0.39 *$ & & & \\
\hline Trust & & $-0.55^{* * *}$ & & \\
\hline Fairness perception & & & $-0.50 * * *$ & \\
\hline General attitude & & & & $-0.34^{* *}$ \\
\hline Adjusted $\mathrm{R}^{2}$ & 0.09 & 0.48 & 0.38 & 0.19 \\
\hline $\mathrm{F}$ & $5.78^{* * *}$ & $40.65^{* * *}$ & $26.96^{* * *}$ & $11.12^{* * *}$ \\
\hline$\Delta \mathrm{R}^{2}$ & 0.11 & 0.39 & 0.29 & 0.10 \\
\hline$\Delta \mathrm{F}$ & $5.78^{* * *}$ & $253.75^{* * *}$ & $156.19^{* * *}$ & $43.27^{* * *}$ \\
\hline
\end{tabular}

Note: ${ }^{*} p<0.05 ;{ }^{* *} p<0.01 ;{ }^{* * *} p<0.001$; AI: anti-incinerator sentiment; ${ }^{a}$ : Dummy variable for female; ${ }^{\mathrm{b}}$ : Dummy variable for rural community.

Similarly, the moderation effect of trust is tested by SPSS the PROCESS procedure. Analysis reveals that, in addition to the main effect of trust $(\beta=-0.52,95 \%$ CI $[-0.64,-0.43], t=-9.92$, $p<0.001)$, there is a significant interaction effect $(\beta=-0.12,95 \% \mathrm{CI}[-0.20,-0.05], t=-3.17, p=0.002)$, indicating that the relationship between risk perception and anti-incinerator sentiment is moderated by institutional trust (Table 8), supporting H 9.

Table 8. Moderation effect of trust.

\begin{tabular}{cccccccc}
\hline \multirow{2}{*}{ Model } & $\boldsymbol{R}^{\mathbf{2}}$ & $\boldsymbol{R}^{2}$-chng & $\boldsymbol{F}$ & Sig. & $\boldsymbol{\beta}$ & $\boldsymbol{t}$ & $\boldsymbol{p}$ \\
\cline { 2 - 7 } & $\mathbf{0 . 6 0 9}$ & & $\mathbf{5 0 . 9 3 4}$ & $\mathbf{0 . 0 0 0}$ & & & \\
\hline Constant & & & & & 4.680 & 111.960 & 0.000 \\
Perceived risk (standardized) & & & & & 0.446 & 8.783 & 0.000 \\
Trust (standardized) & & 0.012 & 10.077 & 0.002 & -0.532 & -9.920 & 0.000 \\
PR*Trust & & 0.122 & -3.174 & 0.002 \\
\hline
\end{tabular}

Spotlight analysis results (Figure 4) reveal that, whether people perceive a lower or a higher level of trust, there is also a significant and positive connection between risk perception and anti-incinerator sentiment (low trust: $\beta=0.57,95 \%$ CI $[0.45,0.69], t=9.37, p<0.001$; high trust: $\beta=0.32,95 \%$ CI $[0.19,0.45], t=4.86, p<0.001)$. Specifically, when people perceived a higher degree of trust, the positive impact of perceived risk on anti-incinerator sentiment would be relieved to some extent. Conversely, in the case of lower trust, not only does risk perception give rise to a higher level of anti-incinerator willingness at any level, but the anti-incinerator tendency increases more sharply.

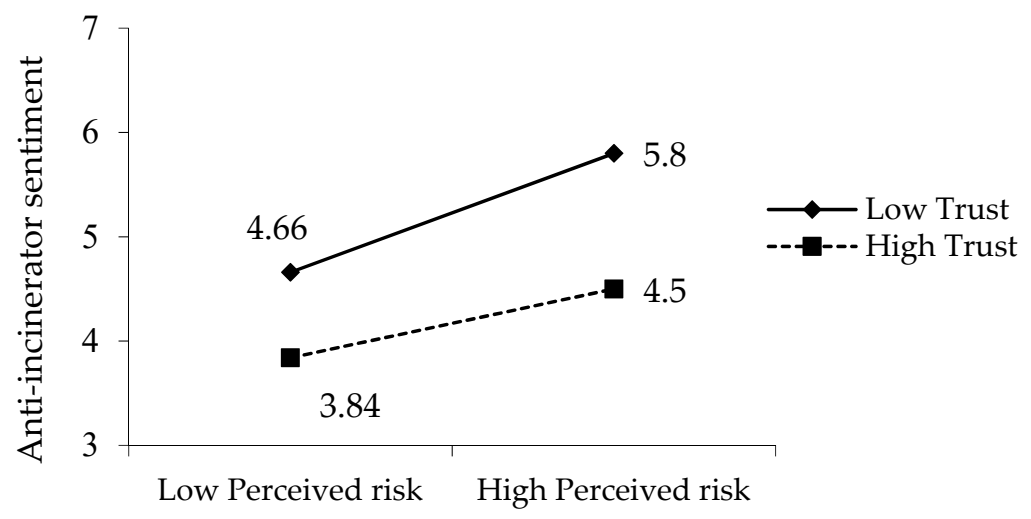

Figure 4. Interaction of perceived risk and trust. 
Analyses reveal that there is no significant interaction between trust and place attachment on predicting anti-incinerator sentiment $(\beta=-0.04,95 \% \mathrm{CI}[-0.13,0.04], t=-1.01, p=0.314)$, rejecting H 10 (see Table 9).

Table 9. Moderation effect of place attachment.

\begin{tabular}{cccccccc}
\hline \multirow{2}{*}{ Model } & $\boldsymbol{R}^{\mathbf{2}}$ & $\boldsymbol{R}^{2}$-chng & $\boldsymbol{F}$ & Sig. & $\boldsymbol{\beta}$ & $\boldsymbol{t}$ & $\boldsymbol{p}$ \\
\cline { 2 - 8 } & $\mathbf{0 . 5 0 2}$ & & $\mathbf{3 2 . 8 2 4}$ & $\mathbf{0 . 0 0 0}$ & & & \\
\hline Constant & & & & & 4.735 & 97.478 & 0.000 \\
Place attachment (standardized) & & & & & 0.081 & 1.384 & 0.168 \\
Trust (standardized) & & 0.002 & 1.018 & 0.314 & -0.044 & -1.009 & 0.314 \\
PA*Trust & & & & &
\end{tabular}

Likewise, the SPSS PROCESS procedure was employed to test the interaction between the independent variable and mediating variable, and we found that the direct effect $\left(c^{\prime}\right)$ of trust and anti-incinerator sentiment was significant $(\beta=-0.362, S E=0.037,95 \% \mathrm{CI}[0.532,0.663], t=-9.723$, $p<0.001)$, and the indirect effect $\left(a^{*} b\right)$ was proved (effect $=-0.187, S E=0.027,95 \% \mathrm{CI}[-0.242,-0.139]$, $p<0.001$ ) (Table 10). H 11 is supported. As for H 17, mediation analysis reveals that the direct effects $\left(c^{\prime}\right)$ of fairness perception and anti-incinerator sentiment are significant $(\beta=-0.232, S E=0.046,95 \% \mathrm{CI}$ $[-0.323,-0.142], t=-5.060, p<0.001)$, and more importantly, the indirect effect $\left(a^{*} b\right)$ is also proved (effect $=-0.265, S E=0.035,95 \%$ CI $[-0.341,-0.203], p<0.001$ ), supporting H 17.

Table 10. Mediation effect of risk perception.

\begin{tabular}{|c|c|c|c|c|c|c|c|c|}
\hline \multirow[t]{2}{*}{ Panel 1: } & \multicolumn{4}{|c|}{ Mediator (Risk Perception) } & \multicolumn{4}{|c|}{ Anti-Incinerator Sentiment } \\
\hline & & Coeff. & $S E$ & $p$ & & Coeff. & $S E$ & $p$ \\
\hline Trust & $a$ & -0.330 & 0.027 & 0.000 & $c^{\prime}$ & -0.362 & 0.037 & 0.000 \\
\hline Perceived risk & - & - & - & - & $b$ & 0.568 & 0.063 & 0.000 \\
\hline Constant & & 6.166 & 0.106 & 0.000 & & 3.274 & 0.407 & 0.000 \\
\hline \multirow[t]{2}{*}{ Panel 2: } & \multicolumn{4}{|c|}{ Soble Test $\left(a^{*} b\right)$} & \multicolumn{4}{|c|}{ 95\% Confidence Intervals } \\
\hline & Value & $S E$ & $t$ & $p$ & & LLCI & & ULCI \\
\hline Direct effect & -0.362 & 0.037 & -9.723 & 0.000 & & -0.435 & & -0.289 \\
\hline Indirect effect & -0.187 & 0.027 & - & - & & -0.242 & & -0.139 \\
\hline
\end{tabular}

Lastly, hierarchical regression analyses reveal that fairness perception significantly and positively predicts institutional trust $(\beta=0.54, t=13.40, p<0.001)$, with fair explanatory power $\left(\Delta R^{2}=0.28\right.$, $\Delta F=179.47, p<0.001$ ). Similarly, there is a significant (positive) connection between trust and general attitude $(\beta=0.42, t=7.80, p<0.001)$. Hence, $\mathrm{H} 15$ and $\mathrm{H} 12$ are supported.

The PROCESS procedure was used to test the moderation effect of fairness perception between risk perception and anti-incinerator sentiment. Analysis reveals that there is a significant interaction effect $(\beta=-0.10,95 \% \mathrm{CI}[-0.18,-0.02], t=-2.58, p=0.010)$, indicating that the relationship between risk perception and anti-incinerator sentiment is also moderated by fairness perception, supporting $\mathrm{H} 16$ (Table 11). Moreover, we find that when risk perception is high, the moderation effect of fairness perception is greater and vice versa, suggesting that fairness and justice play a larger role in the case of higher levels of perceived risk.

As for $\mathrm{H} 19$ hierarchical regression analyses reveal that both procedural fairness $(\beta=-0.51$, $t=-11.06, p<0.001)$ and distributive fairness $(\beta=-0.43, t=-9.13, p<0.001)$ negatively predict anti-incinerator sentiment, and the former $\left(\Delta R^{2}=0.24, \Delta F=122.38, p<0.001\right)$ explains a greater amount of variance than the latter $\left(\Delta R^{2}=0.18, \Delta F=83.36, p<0.001\right)$, indicating that $\mathrm{H} 19$ is not supported. Therefore, in China, procedural fairness perception is more important than distributional fairness perception in predicting anti-incinerator sentiment. 
Table 11. Moderation effect of fairness perception.

\begin{tabular}{cccccccc}
\hline \multirow{2}{*}{ Model } & $\boldsymbol{R}^{2}$ & $\boldsymbol{R}^{2}$-chng & $\boldsymbol{F}$ & Sig. & $\beta$ & $t$ & $p$ \\
\cline { 2 - 8 } & $\mathbf{0 . 5 2 8}$ & & $\mathbf{3 6 . 5 7 9}$ & $\mathbf{0 . 0 0 0}$ & & & \\
\hline Constant & & & & & 0.011 & 0.0446 & 0.964 \\
Fairness perception (standardized) & & & & & -0.264 & -5.235 & 0.000 \\
Perceived risk (standardized) & & 0.001 & 6.663 & 0.000 & -0.094 & -2.581 & 0.000 \\
FP*PR & & & & & & &
\end{tabular}

\section{Discussion}

This study introduces and tests an extended psychological-emotional model focusing on perceived risk, place attachment, institutional trust, fairness perception, and anti-incinerator sentiment in the context of a proposed WtE incinerator in an urban-rural fringe area in Beijing. The results reveal that people's anti-incinerator sentiment, risk perception regarding a community WtE incinerator, and place attachment toward their dwelling place are high, suggesting a generally negative attitude toward community-based energy projects and a positive linkage to their communities. By contrast, institutional trust, whether in governments or facility operators, is rather low, as is fairness perception, including distributive and procedural fairness. Additionally, we find a moderate general attitude toward the WtE incineration industry and technologies, indicating that WtE incineration is accepted as a necessary way to dispose of MSW.

The most intriguing findings of this research are as follows: first, anti-incinerator sentiment is a function of the interaction between risk perception, place attachment, institutional trust, fairness perception, and general attitude from a psychological-emotional perspective. Place attachment is positively associated with anti-incinerator sentiment, consistent with numerous studies on renewable energy projects $[14,19]$. One explanation is that people with a higher level of attachment tend to take their place largely for granted, owing to a lack of competing place experience, refusing any potential upheavals to the residence place [81]. The higher the degree of immobility and rootedness in one place, the more the "home" place is regarded as "an irreplaceable refuge, a site of unreflective security, certainty and familiarity in otherwise insecure, unstable and nameless space" [82] (p. 208). Place attachment and risk perception reinforce one another, suggesting that local residents' sense of place may actually intensify as a socio-cultural response to a perceived threat or stigmatization [14], which, in turn, acts as a situational amplifier of perceived risks. Conversely, trust in authorities, fairness perception, and general attitude represent the negative predictors of anti-incinerator sentiment in our study which replicates many studies on technology acceptance $[4,55,64]$.

Place attachment positively enhances anti-incinerator willingness, through both moderating and mediating paths between risk perception and anti-incinerator sentiment, indicating that it amplifies the positive effect exerted by perceived risk on anti-incinerator sentiment and serves as a bridge connecting the two concepts. Conversely, risk perception acts as a mediator in connecting place attachment and opposing intention toward the incinerator. An impressive body of literature indicates that place-related constructs exhibit different effects and even a lack of significant effects in predicting the acceptance of energy projects. For the most controversial types of facility (such as nuclear power stations, coal mines, and powerlines), place attachment is found to be negatively related to social acceptance (e.g., Devine-Wright [13], Venables et al. [14]); while in the relatively rare studies focused on alternative energy sources such as wind farms (e.g., the South Africa study of Lombard et al. [35]) or tidal energy facilities (e.g., the Northern Ireland study of Devine-Wright [19,34]), the effect appears to be positive, and is likely to be amplified by intensive community consultation and participation. Notably, no effect has been found for solar energy development [83]. In addition, a lack of investigation into the moderation or mediation effects of place attachment between risk perception and opposing willingness may be a possible reason for these contradictory conclusions.

Further, institutional trust not only directly reduces anti-incinerator sentiment and promotes positive general attitude toward developing incinerator projects, but it also negatively moderates the 
impact of perceived risk on protesting willingness, consistent with other studies (e.g., Liu et al., [4]). In the case of high levels of trust, even a greater magnitude of risk perception would make it difficult to generate an inevitable anti-incineration tendency. In contrast, a low level of trust magnifies the impact of risk perception on anti-incinerator sentiment. That is, trust in authorities generally contributes to weakening the negative evaluation of the introduction of renewable energy facilities. Trust also influences anti-incinerator sentiment through lessening risk perception, partially attesting to the effectiveness of the casual model of trust [60]. However, we do not confirm that trust moderates the connection between place attachment and anti-incinerator sentiment. Because we did not consider further factors, such as motivation, value $[84,85]$, environmental and climate change beliefs $[15,86]$, affect $[85,86]$, and personal norms [69], we have failed to discuss whether the associationist model is effective in our analysis. As stated by Boecker et al. [62] (p. 275), "trust and risk judgments are driven by and thus simply indicators of higher order attitudes toward a certain technology which determine acceptance instead." For example, a study indicated that altruism values buoyed wind energy attitudes, while values of traditionalism diminished wind energy support [86].

Finally, fairness perception lessens risk perception and objecting attitudes toward community-based initiatives and promotes institutional trust. Risk perception mediates the connection between fairness and anti-incinerator sentiment, similarly to its role in the casual model of trust. With regard to fairness, we find that procedural fairness plays a more important role in predicting anti-incinerator sentiment than distributive fairness, indicating that, in contrast to the benefit-risk allocation, whether the planning and construction process of risk facilities is open, equal, and transparent has greater weight for people's risk perception and acceptance tendencies. This result implies the importance of information communication and public engagement in decision-making processes, and appears to be more in line with previous literature, which argued that procedural fairness, or participatory justice contributed to the promotion of trust in the relationship between a company and community, and ultimately facilitated the acceptance of community (e.g., Hagget [22]; Lacey et al. [87]; Liebe et al. [88]). However, this contradicts other studies; for example, Visschers et al. noted that outcome fairness, along with general attitudes toward nuclear power, strongly increased decision acceptance, and procedural fairness had only a small impact [55].

\section{Conclusions and Implications}

Based on an extended psychological-emotional model and systematic empirical study, this study addresses a gap in the literature on place attachment $[12,13,89]$, institutional trust $[49,61]$, fairness perception $[55,90]$, and anti-incinerator sentiment with regard to a community $\mathrm{WtE}$ incinerator project in China. The findings show that most of the aforementioned predictors significantly influence public anti-incinerator sentiment.

This study makes a scholarly contribution to research on the social acceptability of community renewable energy and the transformation of human-place relationships disturbed by the introduction of energy projects. The conclusions can be expected to contribute to the improvement of planning and locating policies that take into account local residents' attachments to dwelling places, public participation in the early stages of siting processes, and information communication, which are thought by most scholars to be effective strategies to promote fairness perception and trust in regulatory authorities and companies [22,87]. By enhancing local residents' attachment, or at least not disturbing it, we hope it will help reduce risk perception, discourage people's anti-incinerator sentiment, and promote social acceptance. To increase people's place dependence to their dwelling place, for example, authorities can coordinate the appearance of the building with the local natural landscape or provide local residents with jobs and necessary financial subsidies.

Another important contribution is the confirmation of the importance of fairness perception and institutional trust, which can reduce anti-incinerator attitudes directly and indirectly via risk perception, implying the needed prioritization of public engagement and risk communication, rather than economic compensation, when implementing the renewable energy policy [4,91]. However, as many 
authors have observed, the lack of participating opportunities was a common phenomenon in the siting procedures of renewable energy project, including wind farms, nuclear power stations, unconventional gas development, and $\mathrm{WtE}$ incinerators $[56,66,92]$. At present, during the process of advancing renewable energy policy in China, deficient public participation and inefficient risk communication have been widely criticized, especially during environmental impact assessments. Although a series of regulations and policies have been successively promulgated and implemented, long-term and strenuous efforts are required to ensure genuine public participation and risk management.

We show that trust plays an indispensable role in advancing community renewable energy projects. Trust is a prerequisite for cooperation and requires strong and continuous communication efforts. As stated by Fast et al. [16] (p. 28), "host communities trust in the siting process is independent of their trust in wider energy policy." In the context of China's WtE incinerators, trust is more related to opportunities for meaningful engagement in the decision-making process and more communication with the public about the risks, benefits, and costs associated with controversial facilities. Furthermore, trust is mutual, and the prerequisite for public trust is trust in the public first. In fact, developers often express scepticism regarding the capacities and representativeness of community actors, and community actors view developers as solely motivated by profit, instrumentally using public engagement to gain planning consent. For trust to be built, more positive strategies should be undertaken (for instance, partner identification mechanisms and shared ownership should be adopted within the energy transformation context [23]).

The present study has several limitations. First, there are methodology limitations, including the small sample size used to test the hypotheses, the short time frame of investigation, and the relatively limited risk perception scale, which does not include risks related to landscape deterioration, financial loss or community stigma. As a result, the change trajectories of people's risk attitudes and range of perceptions have not been captured. Second, our conceptual model did not involve other important "higher order" attitudinal factors, such as value, environmental beliefs, and personal norms. Therefore, further research is necessary on these subjects using detailed qualitative analysis and systematic quantitative study; in addition, a longitudinal survey would provide additional insight into respondents' risk perceptions and protective behavioural intentions.

Author Contributions: G.H. and K.M. conceived and designed the surveys and took the lead in writing the article; T.C., Z.L., H.X. and T.Y. performed the surveys and analysed the data, they also co-authored the article by providing advice and feedback during the whole writing process. The order of the authors' names represents the amount of input in the writing of the article.

Funding: This article is part of the research programmes "Public participation paradox and adaptive governance: the perspective of NIMBY crisis" with project number 15BSH026, and "Cooperation governance on public cultural service from the perspective of Project System" with project number 17BZZ006, which are financed by the National Social Science Fund of China (NSSFC).

Acknowledgments: We acknowledge the helpful comments and suggestions for revisions from the editors and anonymous reviewers. All errors are our own.

Conflicts of Interest: The authors declare no conflicts of interest.

\section{References}

1. Ministry of Ecology and Environment of the PRC (MEE). Annual Report on Environmental Pollution Prevention and Control of Solid Wastes in Large and Medium Cities in China in 2017. Available online: http:/ / huanbao.bjx.com.cn/news/20171208/866348.shtml (accessed on 8 December 2017).

2. Cheng, $\mathrm{H} . ; \mathrm{Hu}, \mathrm{Y}$. Municipal solid waste $(\mathrm{msw})$ as a renewable source of energy: Current and future practices in china. Bioresour. Technol. 2010, 101, 3816-3824. [CrossRef] [PubMed]

3. Wan, Z.; Chen, J.; Craig, B. Lessons learned from Huizhou, China's unsuccessful waste-to-energy incinerator project: Assessment and policy recommendations. Utilities Policy 2015, 33, 63-68. [CrossRef]

4. Liu, Y.; Sun, C.; Xia, B.; Cui, C.; Coffey, V. Impact of community engagement on public acceptance towards waste-to-energy incineration projects: Empirical evidence from China. Waste Manag. 2018, 76, 431-442. [CrossRef] [PubMed] 
5. Zhao, X.G.; Jiang, G.W.; Li, A.; Wang, L. Economic analysis of waste-to-energy industry in China. Waste Manag. 2016, 48, 604-618. [CrossRef] [PubMed]

6. National Development and Reform Commission of the PRC (NDRC). National Planning for Construction of Harmless Treatment Facilities for Urban MSW. 2016. Available online: http:/ / www.ndrc.gov.cn/zcfb / zcfbghwb/201701/t20170122_836134.html (accessed on 31 December 2016).

7. National Energy Administration of the PRC (NEA). National Monitoring and Evaluation Report on Renewable Energy Power Development in 2017. Available online: http://zfxxgk.nea.gov.cn/auto87/ 201805/t20180522_3179.htm (accessed on 11 May 2018).

8. Wester-Herber, M. Underlying concerns in land-use conflicts-the role of place-identity in risk perception. Environ. Sci. Policy 2004, 7, 109-116. [CrossRef]

9. Huang, Y.; Ning, Y.; Zhang, T.; Fei, Y. Public acceptance of waste incineration power plants in China: Comparative case studies. Habitat Int. 2015, 47, 11-19. [CrossRef]

10. Liu, Z.; Liao, L.; Mei, C. Not-in-my-backyard but let's talk: Explaining public opposition to facility siting in urban China. Land Use Policy 2018, 77, 471-478. [CrossRef]

11. Ren, X.; Che, Y.; Yang, K.; Tao, Y. Risk perception and public acceptance toward a highly protested Waste-to-Energy facility. Waste Manag. 2016, 48, 528-539. [CrossRef]

12. Devine-Wright, P. Rethinking NIMBYism: The role of place attachment and place identity in explaining place-protective action. J. Community Appl. Soc. Psychol. 2009, 19, 426-441. [CrossRef]

13. Devine-Wright, P. Explaining "NIMBY" objections to a power line: The role of personal, place attachment and project-related factors. Environ. Behav. 2013, 45, 761-781. [CrossRef]

14. Venables, D.; Pidgeon, N.; Parkhill, K.; Henwood, K.; Simmons, P. Living with nuclear power: Sense of place, proximity, and risk perceptions in local host communities. J. Environ. Psychol. 2012, 32, 371-383. [CrossRef]

15. Dreyer, S.; Polis, H.; Jenkins, L. Changing tides: Acceptability, support, and perceptions of tidal energy in the united states. Energy Res. Soc. Sci. 2017, 29, 72-83. [CrossRef]

16. Fast, S.; Mabee, W. Place-making and trust-building: The influence of policy on host community responses to wind farms. Energy Policy 2015, 81, 27-37. [CrossRef]

17. Petrova, M. From NIMBY to acceptance: Toward a novel framework—VESPA—for organizing and interpreting community concerns. Renew. Energy 2016, 86, 1280-1294. [CrossRef]

18. Devine-Wright, P.; Howes, Y. Disruption to place attachment and the protection of restorative environments: A wind energy case study. J. Environ. Psychol. 2010, 30, 271-280. [CrossRef]

19. Devine-Wright, P. Place attachment and public acceptance of renewable energy: A tidal energy case study. J. Environ. Psychol. 2011, 31, 336-343. [CrossRef]

20. Liebe, U.; Dobers, G. Decomposing public support for energy policy: What drives acceptance of and intentions to protest against renewable energy expansion in Germany? Energy Res. Soc. Sci. 2019, 47, $247-260$. [CrossRef]

21. Von Wirth, T.; Grêt-Regamey, A.; Moser, C.; Stauffacher, M. Exploring the influence of perceived urban change on residents' place attachment. J. Environ. Psychol. 2016, 46, 67-82. [CrossRef]

22. Hagget, $\mathrm{C}$. Planning and Persuasion: Public engagement in renewable energy decision-making. In Renewable Energy and the Public: From NIMBY to Participation; Devine-Wright, P., Ed.; Earthscan: London, UK, 2011; pp. 15-29.

23. Goedkoop, F.; Devine-Wright, P. Partnership or placation? The role of trust and justice in the shared ownership of renewable energy projects. Energy Res. Soc. Sci. 2016, 17, 135-146. [CrossRef]

24. Hall, N.; Ashworth, P.; Devine-Wright, P. Societal acceptance of wind farms: Analysis of four common themes across Australian case studies. Energy Policy 2013, 58, 200-208. [CrossRef]

25. Sonnberger, M.; Ruddat, M. Local and socio-political acceptance of wind farms in Germany. Technol. Soc. 2017, 51, 56-65. [CrossRef]

26. Cresswell, T. Place: A Short Introduction; Blackwell Publishing: London, UK, 2004.

27. Stedman, R.C. Toward a social psychology of place: Predicting behavior from place-based cognitions, attitude, and identity. Environ. Behav. 2002, 34, 561-581. [CrossRef]

28. Manzo, L.; Perkins, D. Finding common ground: The importance of place attachment to community participation and planning. J. Plan. Lit. 2006, 20, 335-350. [CrossRef]

29. Lewicka, M. What makes neighborhood different from home and city? Effects of place scale on place attachment. J. Environ. Psychol. 2010, 30, 35-51. [CrossRef] 
30. Twigger-Ross, C.; Uzzell, D.L. Place and identity processes. J. Environ. Psychol. 1996, 16, 139-169. [CrossRef]

31. Harris, P.; Brown, B.; Werner, C. Privacy regulation and place attachment: Predicting attachments to a student family housing facility. J. Environ. Psychol. 1996, 16, 287-301. [CrossRef]

32. Manzo, L.; Kleit, R.; Couch, D. Moving three times is like having your house on fire once: The experience of place and impending displacement among public housing residents. Urban Stud. 2008, 45, 1855-1878. [CrossRef]

33. Fried, M. Continuities and discontinuities of place. J. Environ. Psychol. 2000, 20, 193-205. [CrossRef]

34. Devine-Wright, P. Enhancing local distinctiveness fosters public acceptance of tidal energy: A UK case study. Energy Policy 2011, 39, 83-93. [CrossRef]

35. Lombard, A.; Ferreira, S. Residents' attitudes to proposed wind farms in the west coast region of South Africa: A social perspective from the south. Energy Policy 2014, 66, 390-399. [CrossRef]

36. Wolsink, M. Contested environmental policy infrastructure: Socio-political acceptance of renewable energy, water, and waste facilities. Environ. Impact Assess. 2010, 30, 302-311. [CrossRef]

37. Jessup, B. Plural and hybrid environmental values: A discourse analysis of the wind energy conflict in Australia and the United Kingdom. Environ. Politics 2010, 19, 21-44. [CrossRef]

38. Cass, N.; Walker, G. Emotion and rationality: The characterisation and evaluation of opposition to renewable energy projects. Emot. Space Soc. 2009, 2, 62-69. [CrossRef]

39. Jasper, J.M. The emotions of protest: Affective and reactive emotions in and around social movements. Sociol. Forum 1998, 13, 397-424. [CrossRef]

40. Bailey, E.; Devine-Wright, P.; Batel, S. Using a narrative approach to understand place attachments and responses to power line proposals: The importance of life-place trajectories. J. Environ. Psychol. 2016, 48, 200-211. [CrossRef]

41. Dan, V. Nimby or not? Exploring the relevance of location and the politics of voiced opinions in renewable energy siting controversies. Energy Policy 2007, 35, 2705-2714.

42. Bernardo, F. Impact of place attachment on risk perception: Exploring the multidimensionality of risk and its magnitude. Estud. Psicol. 2013, 34, 323-329. [CrossRef]

43. De Dominicis, S.; Fornara, F.; Cancellieri, U.G.; Twigger-Ross, C.; Bonaiuto, M. We are at risk, and so what? Place attachment, environmental risk perceptions and preventive coping behaviours. J. Environ. Psychol. 2015, 43, 66-78. [CrossRef]

44. Lima, M.L.; Marques, S. Towards successful social impact assessment follow-up: A case study of psychosocial monitoring of a solid waste incinerator in the north of Portugal. Impact Assess. Proj. Apprais. 2005, 23, 227-233. [CrossRef]

45. Pellizzone, A.; Allansdottir, A.; Franco, R.D.; Muttoni, G.; Manzella, A. Exploring public engagement with geothermal energy in southern Italy: A case study. Energy Policy 2015, 85, 1-11. [CrossRef]

46. Rousseau, D.M.; Sitkin, S.B.; Burt, R.S.; Camerer, C. Not so different after all: A cross-discipline view of trust. Acad. Manag. Rev. 1998, 23, 815-823. [CrossRef]

47. Siegrist, M.; Cvetkovich, G.; Roth, C. Salient value similarity, social trust, and risk/benefit perception. Risk Anal. 2000, 20, 353-362. [CrossRef]

48. Kim, Y.; Kim, W.; Kim, M. An international comparative analysis of public acceptance of nuclear energy. Energy Policy 2014, 66, 475-483. [CrossRef]

49. Ceglarz, A.; Beneking, A.; Ellenbeck, S.; Battaglini, A. Understanding the role of trust in power line development projects: Evidence from two case studies in Norway. Energy Policy 2017, 110, 570-580. [CrossRef]

50. Folke, C. Resilience-The emergence of a perspective for social-ecological systems analysis. Glob. Environ. Chang. 2006, 16, 253-267. [CrossRef]

51. Fulmer, C.; Gelfand, M. At what level (and in whom) we trust: Trust across multiple organizational levels. J. Manag. 2012, 38, 1167-1230. [CrossRef]

52. Mah, D.; Hills, P.; Tao, J. Risk perception, trust and public engagement in nuclear decision-making in Hong Kong. Energy Policy 2014, 73, 368-390. [CrossRef]

53. Poortinga, W.; Pidgeon, N. Exploring the dimensionality of trust in risk regulation. Risk Anal. 2003, 23, 961-972. [CrossRef]

54. Stirling, A. Transforming power: Social science and the politics of energy choices. Energy Res. Soc. Sci. 2014, 1, 83-95. [CrossRef] 
55. Visschers, V.; Siegrist, M. Fair play in energy policy decisions: Procedural fairness, outcome fairness and acceptance of the decision to rebuild nuclear power plants. Energy Policy 2012, 46, 292-300. [CrossRef]

56. Guo, Y.; Ren, T. When it is unfamiliar to me: Local acceptance of planned nuclear power plants in china in the post-Fukushima era. Energy Policy 2017, 100, 113-125. [CrossRef]

57. Upreti, B.; Dan, V. National renewable energy policy and local opposition in the UK: The failed development of a biomass electricity plant. Biomass Bioenergy 2004, 26, 61-69. [CrossRef]

58. Bronfman, N.; Vázquez, E. A cross-cultural study of perceived benefit versus risk as mediators in the trust-acceptance relationship. Risk Anal. 2011, 31, 1919-1934. [CrossRef] [PubMed]

59. Xiao, Q.; Liu, H.; Feldman, M. How does trust affect acceptance of a nuclear power plant (NPP): A survey among people living with Qinshan NPP in China. PLoS ONE 2017, 12, e0187941. [CrossRef]

60. Eiser, J.R.; Miles, S.; Frewer, L.J. Trust, perceived risk and attitudes towards food technologies. J. Appl. Soc. Psychol. 2002, 32, 2423-2433. [CrossRef]

61. Earle, T.C. Trust in risk management: A model-based review of empirical research. Risk Anal. 2010, 30, 541-574. [CrossRef] [PubMed]

62. Boecker, A.; Nocella, G. A Critical Account of the Relationship between Institutional Trust, Risk Perception, and Technology Acceptance with an Application to Genetically Modified Foods. In Proceedings of the 99th Seminar, Bonn, Germany, 8-10 February 2006; European Association of Agricultural Economists: Wageningen, The Netherlands, 2006; pp. 275-284.

63. Poortinga, W.; Pidgeon, N. Trust in risk regulation: Cause or consequence of the acceptability of GM food? Risk Anal. 2005, 25, 199-209. [CrossRef] [PubMed]

64. Kalkbrenner, B.; Roosen, J. Citizens' willingness to participate in local renewable energy projects: The role of community and trust in Germany. Energy Res. Soc. Sci. 2016, 13, 60-70. [CrossRef]

65. Walker, G.; Devine-Wright, P. Community Renewable Energy: What does it Mean? Energy Policy 2008, 36, 497-500. [CrossRef]

66. Ottinger, G.; Hargrave, T.; Hopson, E. Procedural justice in wind facility siting: Recommendations for state-led siting processes. Energy Policy 2014, 65, 662-669. [CrossRef]

67. Huijts, N.; Molin, E.; Steg, L. Psychological factors influencing sustainable energy technology acceptance: A review-based comprehensive framework. Renew. Sustain. Energy Rev. 2015, 16, 525-531. [CrossRef]

68. The People's Government of Beijing Municipality (PGBM). Three-Year (2013-2015) Implementation Plan for the Construction of Municipal Solid Waste Treatment Facilities in Beijing. 2013. Available online: http:/ / www.bjskjy.org/S_Show.asp?ID=538 (accessed on 17 April 2013).

69. De Groot, J.; Steg, L. Morality and nuclear energy: Perceptions of risks and benefits, personal norms, and willingness to take action related to nuclear energy. Risk Anal. 2010, 30, 1363-1373. [CrossRef]

70. Prati, G.; Zani, B. The effect of the Fukushima nuclear accident on risk perception, antinuclear behavioral intentions, attitude, trust, environmental beliefs, and values. Environ. Behav. 2013, 45, 782-798. [CrossRef]

71. Brewer, N.; Chapman, G.; Gibbons, F.; Gerrard, M.; McCaul, K.; Weinstein, N. Meta-analysis of the relationship between risk perception and health behavior: The example of vaccination. Health Psychol. 2007, 26, 136-145. [CrossRef]

72. Fornara, F.; Bonaiuto, M.; Bonnes, M. Cross-validation of abbreviated perceived residential environment quality (PREQ) and neighborhood attachment (NA) indicators. Environ. Behav. 2010, 42, 171-196. [CrossRef]

73. Bickerstaff, K.; Walker, G.; Bulkely, H. Energy in a Changing Climate. Social Equity and Low Carbon Energy; Zed Books: London, UK; New York, NY, USA, 2013.

74. Tyler, T. Social justice: Outcome and procedure. Int. J. Psychol. 2000, 35, 117-125. [CrossRef]

75. King, T.; Murphy, K. Procedural Justice as a Component of the Not in My Backyard (NIMBY) Syndrome: Understanding Opposition to the Building of a Desalination Plant in Victoria; Alfred Deakin Research Institute: Geelong, Australia, 2012.

76. Hayes, A. Introduction to Mediation, Moderation and Conditional Process Analysis-A Regression-Based Approach; Guilford Press: New York, NY, USA, 2013.

77. Hayes, A. Beyond Baron and Kenny: Statistical mediation analysis in the new millennium. Commun. Monogr. 2009, 76, 408-420. [CrossRef]

78. Cohen, J.; Cohen, P. Applied multiple regression/correlation analysis for the behavioral sciences. J. $R$. Stat. Soc. 2003, 52, 691.

79. Field, A. Discovering Statistics Using IBM SPSS Statistics, 3rd ed.; Sage Publications Ltd.: London, UK, 2012. 
80. Aiken, L.; West, S. Multiple Regression: Testing and Interpreting Interactions; Thousand Oaks; Sage Publications Ltd.: London, UK, 1991.

81. Hummon, D. Community Attachment, Local Sentiment and Sense of Place; Altman, I., Low, S., Eds.; Plenum Press: New York, NY, USA, 1992; pp. 253-278.

82. Dovey, K. Home and homelessness. In Home Environments; Altman, I., Werner, C.M., Eds.; Plenum Press: New York, NY, USA, 1985; pp. 33-64.

83. Carlisle, J.; Kane, S.; Solan, D.; Joe, J.C. Support for solar energy: Examining sense of place and utility-scale development in California. Energy Res. Soc. Sci. 2014, 3, 124-130. [CrossRef]

84. Axsen, J. Citizen acceptance of new fossil fuel infrastructure: Value theory and Canada's northern gateway pipeline. Energy Policy 2014, 75, 255-265. [CrossRef]

85. Perlaviciute, G.; Steg, L.; Contzen, N.; Roeser, S.; Huijts, N. Emotional Responses to Energy Projects: Insights for Responsible Decision Making in a Sustainable Energy Transition. Sustainability 2018, 10, 2526. [CrossRef]

86. Bidwell, D. The role of values in public beliefs and attitudes towards commercial wind energy. Energy Policy 2013, 58, 189-199. [CrossRef]

87. Lacey, J.; Carr-Cornish, S.; Zhang, A.; Eglinton, K.; Moffat, K. The art and science of community relations: Procedural fairness at newmont's waihi gold operations, New Zealand. Resour. Policy 2017, 52, $245-254$. [CrossRef]

88. Liebe, U.; Bartcazak, A.; Meyerhoff, J. A turbine is not only a turbine: The role of social context and fairness characteristics for the local acceptance of wind power. Energy Policy 2017, 107, 300-308. [CrossRef]

89. Anton, C.; Lawrence, C. The relationship between place attachment, the theory of planned behaviour and residents' response to place change. J. Environ. Psychol. 2016, 47, 145-154. [CrossRef]

90. Gross, C. Community perspectives of wind energy in Australia: The application of a justice and community fairness framework to increase social acceptance. Energy Policy 2007, 35, 2727-2736. [CrossRef]

91. Lienhoop, N. Acceptance of wind energy and the role of financial and procedural participation: An investigation with focus groups and choice experiments. Energy Policy 2018, 118, 97-105. [CrossRef]

92. Whitton, J.; Brasier, K.; Charnley-Parry, I.; Cotton, M. Shale gas governance in the United Kingdom and the United States: Opportunities for public participation and the implications for social justice. Energy Res. Soc. Sci. 2017, 26, 11-22. [CrossRef] 